\title{
Teachers' Perspective on Personal Learning Environments via Learning Management Systems Platform
}

\author{
https://doi.org/10.3991/ijet.v16i24.27433 \\ Sarah Alserhan $\left.{ }^{\bowtie}\right)$, Noraffandy Yahaya \\ Universiti Teknologi Malaysia, Johor Bahru, Malaysia \\ sarah.alsarhanehotmail.com
}

\begin{abstract}
In recent years, the landscapes of teaching and learning has changed because of the utilization of information and communications technologies. In this context, the most illustrative innovations are Learning Management Systems (LMS) and Personal Learning Environments (PLEs). Despite of the LMS and PLEs popularity in educational contexts as well as the expand set of tools and services that they offer to learners and teachers; they are still in fancy stages. In order to present the challenges Personal Learning Environments were presented; however, it is obvious that PLEs will not replace LMS. Therefore, both types of environments should coexist and interact. In this manner, the current study took teachers' perspective on integrating the third generation LMS into PLEs. In addition, this study conducted to find out the teachers' perspective on how the LMS could enhance PLEs in terms of planning before applying the PLE's; designing a framework in the PLE's; implementing the PLEs; interacting in PLEs; managing the learning process through the PLEs and utilizing technology in PLEs. The participants of the study were 575 teachers who were selected randomly from Saudi Arabia schools. The findings of this study found that teachers must apply a positive teaching approach, holding that knowledge is composed upon student-to-student interaction as well as student-to-teacher interaction. Furthermore, this study revealed that teachers must enterprise, deliver, and support $\mathrm{K}-12$ online learning.
\end{abstract}

Keywords - personal learning environments, learning management systems, teachers' perspective

\section{Introduction}

The rapid growth of internet technologies has changed the way formal learning facilitates the educational environments. Previously, classroom was known as the only medium of communication and information sharing context. However, current e-learning environment such as Learning Management System (LMS) and Personal Learning Environments are recognized as the platforms were utilized and are extensively recognized in the educational contexts [1]. Therefore, in the perspective of Tuah et al. [1],with the adoption of Web 2.0 in e-learning's model, e-learning has enthusiastically 
transported classroom content (e.g., notes, tutorial, etc.) to its participants (e.g., teachers and students), which are the focus of this paper to find out the teachers' perspective on integrating the LMS into PLEs [1].

The utilization of Information and Communication Technologies (ICT) to education, triggers changes that affect the way in which people learn and teach, raising new challenges in for learners, teachers and institutions as the ICT makes obtainable the fresh tools to support learning activities that can help to satisfy needs of teachers who are directly the purpose of this study as well as learners [2]. However, in the perspective of Conde et al. [2] this support needs that numerous matters be addressed such as the variety of technologies and tools employed in learning contexts forces students to utilize several different systems during their training and studies; secondly, the institutions should not regard learning as being limited to formal learning environments, as people learn throughout their lives in many informal contexts which are known as lifelong learning. Furthermore, Tuah et al. [1] considered that the application of different components like social media in learning environment will help users to create, preserve and reorganize their own content, which these components present a new way of learning in PLEs.

Regarding the significant role of PLEs, they all have a mutual point considering the integration of formal and informal learning with the purpose of motivating peer learning. In this context, Gaytan [3] mentioned the significance of PLEs in e-learning fields address the issues, in which associated with learner personalization and control is increasingly beneficial. Furthermore, Gaytan [3]indicated that PLEs involve consuming externally hosted Web 2.0 facilities and tools intended to improve the sharing of learning resources and materials among learners. Moreover, Ellili-Cherif and Hadba [4] considered that these platforms help learners to managing their pedagogical practices and participating in the generation of cooperative knowledge. This is while, it should place the accountability for establishing learning on the learners, which makes it an integrally self-directed practice. Fueled with the significant role of PLEs, Mundkur and Ellickson[5] confirmed that PLEs technological methods are not only pedagogical tactics designed to meet learners' exclusive goals. Thus, learners are able to build and grow their environments through being active on web-based and social networking platforms with utilizing the crowdsourcing of ideas, while remarking on and sharing educational posts. Aresta, et al. [6] believe that the PLEs reflect human and social dimensions as places, where knowledge is socially created and distributed.

On the other hand, Shaikh and Khoja [7] mentioned the lack of support to the PLEs make learning environments ineffective. In the same vein, Martinez et al. [8] believe that there is no doubt whatsoever at this stage that the degree of success or failure of some models and tools used in teaching or learning processes largely depends on the good, bad or non- existent training of teachers for the correct technical and didactic utilization of the aforesaid models and tools. Therefore, at this stage the perspective of teachers is too important, which is the focus of this study. Thus, all of this in the perspective of Cejudo[9] implies a formal change for teachers both in terms of mind-set and about action design, planning and implementation. 
Driven with the significant of teachers' perspective, Moreillon[10] stated that the learners would also be able to comprehend and understand the latest tools in their interest and make the learning process more comfortable. To compare with the role of teachers, Schaffert and Hilzensauer [11] revealed that most teachers are not comfortable with utilizing technology-driven equipment. Therefore, this would be a problematic issue if educators are not in the know to the services desired to ease PLEs. In this occasion, Shaikh et al. [7] considered that PLEs only work if the teacher can develop a multifunctional and robust association between teachers and the PLEs. Therefore, the current study seeks to investigate the teachers' perspective on integrating the third generation LMS into PLEs.

Regarding all considered issues, it should be considered that integrating LMS into the PLEs is still at its fancy stage, and it requires the adaptation of both, which can be inferred as the major goal of the study. In a study conducted by Conde et al. [2], the uses of web services and interoperability specifications facilitates the opening up of PLEs and LMSs, although they are very laborious. To provide a solution to the interconnection and interoperability, this paper seeks to investigate the integration of LMS into the PLEs.

\section{Research questions}

The research questions in this research are:

1. How the LMS enhances PLEs according to the teachers' perspective in terms of:

(a) planning before applying the PLE's.

(b) designing the theoretical framework in the PLE's.

(c) implementing the PLEs.

(d) interacting in PLEs.

(e) managing the learning process utilizing the PLEs; and

(f) employing technology in PLEs.

2. What are the relationship of:

(a) demographic variables with teachers' roles domains in PLEs?

(b) professional related variables with domains of teachers' role?

\section{$3 \quad$ Research methods}

The Survey study investigated teachers' perspective on integrating the third generation LMS into PLEs, to collect the relevant data regarding research questions the researcher distributed the questionnaire to random sampling K-12 teachers in Saudi Arabia schools. The latter involves an empirical extension in which the content needs to be valid based on the aspect of factor analysis which entails the content to be constructed using statistical models [12]. Adding to the factorial validity, its application is also unique. It is applied in the context of many dimensions with different general attributes to help measure a needed domain [12]. Another assessment related to instruments usually involves inferential statistics. 


\subsection{Population and sampling}

The designed survey in this study was conducted on total of 575 teachers who were selected randomly out of the population of Saudi Arabia schools' teachers. To examine the research instrumentations' validity and reliability, this study conducted a pilot study on around 20 percent of teachers from the population. The pilot study was entirely designed same as the procedures of an entire data collection. This kind of study was first conducted among the total of 112 instructors selected from Saudi Arabia Schools.

\subsection{Instrumentation}

This study modified the Delphi method based on a study was conducted by [7] on 34 international experts to find out the university instructor roles according to PLEs' theoretical perspectives in learner-centered context. The 5-point Likert scales utilized to analyze the collected data. The questionnaire was designed based on two sections: the first section concerns the respondents' demographic information, followed by the second section to examine the evaluation of the entire roles. The questionnaire was designed in a paper-based and web-based format to be accessible online. The webbased questionnaire was designed to collect the data for conducting the pilot study to collect the extensive data quickly, and employ examined forms and sample questions rather than having to design them, and take advantage of the extensive use of the Web by individuals today, including its use as a site for social networking [13].

\section{$4 \quad$ Results and discussion}

\subsection{Demographic characteristics of the participants}

The study sample consisted of 575 participants, in which the age of $41.4 \%$ of them is $33-42$ years; the age of $32.7 \%$ of them is $23-32$ years, while the age of $22.1 \%$ of them is $53-52$ years old. In addition, more than half $(60.0 \%)$ of participants were females, while $40.0 \%$ of them were males. Regarding the major of participants' study, science constitutes $18.8 \%$ of them, mathematics constitutes $17.4 \%$, while computer Science constitutes $16.9 \%$ (Table 1 ).

Table 1. Sample distribution based on their demographic characteristics

\begin{tabular}{|l|c|c|}
\hline \multicolumn{1}{|c|}{ Variables } & Number & Percentage \\
\hline \multicolumn{2}{|l|}{ Age groups } \\
\hline $23-32$ years & 188 & 32.7 \\
\hline $33-42$ years & 238 & 41.4 \\
\hline $53-52$ years & 127 & 22.1 \\
\hline $53-62$ years & 22 & 3.8 \\
\hline Gender & 230 & 40.0 \\
\hline Male & 345 & 60.0 \\
\hline Female & & \\
\hline
\end{tabular}


Paper-Teachers' Perspective on Personal Learning Environments via Learning Management Systems...

\begin{tabular}{|l|c|c|}
\hline \multicolumn{1}{|c|}{ Variables } & Number & Percentage \\
\hline Major & 96 & 16.7 \\
\hline Social science & 108 & 18.8 \\
\hline Science & 100 & 17.4 \\
\hline Mathematics & 40 & 7.0 \\
\hline English language & 97 & 16.9 \\
\hline Computer Science & 30 & 5.2 \\
\hline Arts & 104 & 18.1 \\
\hline Other & & \\
\hline
\end{tabular}

\subsection{Participants overall score in teacher's roles domains in PLEs}

Regarding the mean score of teacher's roles domains in PLEs. The highest mean score of teacher's roles domains in PLEs is 4.29 which was for the variable "use of technology" with a mean percentage of $85.8 \%$, followed by the domain "Planning and Design" and "Management and Administration" with a mean score 4.27 (85.4\%), while the lowest mean score was the domain "Instructor and Learning" with a mean score 4.23 (Table 2).

Table 2. Comparison of the mean scores of teacher's roles domains in PLEs

\begin{tabular}{|l|c|c|c|}
\hline \multicolumn{1}{|c|}{ Domain } & Mean & SD & Percentage \\
\hline Planning and Design & 4.27 & .51 & 85.4 \\
\hline Instructor and Learning & 4.23 & .53 & 84.6 \\
\hline Communication and Interaction & 4.26 & .56 & 85.2 \\
\hline Management and Administration & 4.27 & .62 & 85.4 \\
\hline Use of Technology & 4.29 & .54 & 85.8 \\
\hline
\end{tabular}

Max. Mean Score $=5$, Min. Score $=1$

\subsection{Planning and design domain}

Regarding the teachers' role in the planning and design domain in PLEs in table 3. The roles of "Planner" and "Learning designer" got the highest mean score (4.30), while the role of "Programmer" got the lowest mean score (4.23). The role of "Context analyzer" got a mean score of 4.24 out of 5 . (Table 3 ). Table 3 shows the Teacher's role as instructor and learning in PLEs.

Table 3. Teacher's role in planning and design in the PLEs

\begin{tabular}{|l|c|c|c|}
\hline Teacher's role in planning and design in the PLEs & Mean & SD & Percentage \\
\hline Planner & 4.30 & .62 & 86.0 \\
\hline Context analyzer & 4.24 & .64 & 84.8 \\
\hline Learning designer & 4.30 & .57 & 86.0 \\
\hline Programmer & 4.23 & .65 & 84.6 \\
\hline
\end{tabular}

Max. Mean Score =5, Min. Score = 1 


\subsection{Instructor and learning domain}

Table 4 illustrates the teacher's roles in instructor and learning, the role of "Innovator" got the maximum mean score (4.32), followed by the role "Creativity catalyst" (4.29), while the role "Enquirer" got the lowest mean score (4.05) out of (5). The role "Mentor" got the mean score 4.28, and the role "Instructor" got the mean score 4.25.

Table 4. Teacher's role as instructor and learning in PLEs

\begin{tabular}{|l|c|c|c|}
\hline Teacher's role as instructor and learning in PLEs & Mean & SD & Percentage \% \\
\hline Instructor & 4.25 & .59 & 85.0 \\
\hline Theorizer & 4.17 & .66 & 83.4 \\
\hline Learner & 4.17 & .69 & 83.4 \\
\hline Critical reviewer & 4.16 & .73 & 83.2 \\
\hline Enquirer & 4.05 & 1.02 & 81.0 \\
\hline Mentor & 4.28 & .67 & 85.6 \\
\hline Creativity catalyst & 4.29 & .62 & 85.8 \\
\hline Innovator & 4.32 & .63 & 86.4 \\
\hline
\end{tabular}

Max. Mean Score $=5$, Min. Score $=1$

\subsection{Communication and interaction}

Moreover, as showed in table 5 the highest mean score within the domain of teacher's communication and interaction in PLEs was observed in the role as "Participant" with a mean score (4.32), followed by the role "Facilitator" and "Motivator" with a mean score (4.30) as shown in table 5. On the other hand, the lowest mean score in this domain was observed in the roles "Communicator" and "Moderator" with a mean score (4.21) out of (5).

Table 5. Teacher's role in communication and interaction in PLEs

\begin{tabular}{|l|c|c|c|}
\hline Teacher's role in communication and interaction in PLEs & Mean & SD & Percentage \% \\
\hline Collaborator & 4.22 & .68 & 84.4 \\
\hline Facilitator & 4.30 & .62 & 86.0 \\
\hline Communicator & 4.21 & .68 & 84.2 \\
\hline Moderator & 4.21 & .68 & 84.2 \\
\hline Advertiser & 4.25 & .73 & 85.0 \\
\hline Participant & 4.32 & .71 & 86.4 \\
\hline Motivator & 4.30 & .70 & 86.0 \\
\hline
\end{tabular}

Max. Mean Score $=5$, Min. Score $=1$ 


\subsection{Management and administration}

Table 6 shows the Teacher's role in management and administration in PLEs. The table shows that the highest mean score of Teacher's roles in management and administration in PLEs is 4.32 which was for the role "Guide" with a mean percentage of $86.4 \%$, followed by 4.29 for the role "Change agent" with a mean percentage of $85.8 \%$, while the role "Evaluator" got the lowest mean score (4.24) out of (5).

Table 6. Teacher's role in management and administration in PLEs

\begin{tabular}{|l|c|c|c|}
\hline Teacher's role in management and administration in PLEs & Mean & SD & Percentage \% \\
\hline Change agent & 4.29 & .67 & 85.8 \\
\hline Administrative manager & 4.26 & .68 & 85.2 \\
\hline Guide & 4.32 & .68 & 86.4 \\
\hline Evaluator & 4.24 & .63 & 84.8 \\
\hline
\end{tabular}

Max. Mean Score $=5$, Min. Score $=1$

\subsection{Use of technology}

Table 7 shows the teacher's role in technology use in PLEs, the highest mean score was observed in the role "Digital literacy expert" with a mean score (4.38), followed by the role "Digital technology expert" with a mean score (4.32), while the lowest mean score was observed in the role "Sharer or collector" with a mean score (4.18) as shown in table 7 .

Table 7. Teacher's role in technology use in PLEs

\begin{tabular}{|l|c|c|c|}
\hline \multicolumn{1}{|c|}{ Teacher's role in technology use in PLEs } & Mean & SD & Percentage \\
\hline Master artist & 4.30 & .86 & 86.0 \\
\hline Sharer or collector & 4.18 & .71 & 83.6 \\
\hline Network manager & 4.26 & .65 & 85.2 \\
\hline Digital technology expert & 4.32 & .63 & 86.4 \\
\hline Digital literacy expert & 4.38 & .61 & 87.6 \\
\hline
\end{tabular}

Max. Mean Score $=5$, Min. Score $=1$

\subsection{Relationship of demographic variables with teachers' roles domains in PLEs}

Impendent sample $t$ test was done to show the differences in the in the mean score of teachers' roles in PLEs with regard to their gender. Table 8 showed that there was no significant difference in the mean score of all teachers' roles in PLEs with regard to their gender $(\mathrm{p}>0.05)$.

In addition, as showed in table. 9 there was no significant difference in the mean score of teachers' roles in PLEs with regard to their age groups $(\mathrm{p}>0.05)$. On the other hand, there was a significant difference in the mean score of "Planning and Design" 
with regard to their age groups $(\mathrm{p}<0.05)$. Post hoc showed that the difference was observed between the age groups 23-32 years and 53-62 years in favor to participants who have the age group 23-32 years.

As showed in table 10 there was a significant difference in the mean score of teachers' roles in PLEs (Planning and Design) with regard to their major field $(\mathrm{p}<0.05)$. Post hoc showed that the difference was observed between social science and computer science in favor to participants who have the major "computer science". In addition, there was a significant difference in the mean score of teachers' roles in PLEs (Instructor and Learning) with regard to their major field $(\mathrm{p}<0.05)$. Post hoc showed that the difference was observed between social science and computer science in favor to participants who have the major "computer science".

Moreover, there was a significant difference in the mean score of teachers' roles in PLEs (Management and administration) with regard to their major field $(p<0.05)$. Post hoc showed that the difference was observed between social science and computer science in favor to participants who have the major "computer science". In addition, there was a significant difference in the mean score of teachers' roles in PLEs (Use of Technology) with regard to their major field $(\mathrm{p}<0.05)$. Post hoc showed that the difference was observed between social science and computer science in favor to participants who have the major "computer science". On the other hand, there was no significant difference in the mean score of teachers' roles in PLEs (Communication and Interaction) with regard to their major field ( $\mathrm{p}>0.05)$.

To sum up, the findings of this study showed that the experience level plays a significant role in teachers' performance; while the findings showed that teachers' role play differently according to teachers' experience. For instance, teachers with three years of experience look to play the highest role in the entire domains. However, this role is the least for the teachers with less than one year of teaching experience. Furthermore, the findings of this study revealed that the mode of teaching is established to be expressively different under each domain of teachers. For instance, blackboard has the highest score in the entire domains of the teacher's role however others show the lowest mean score. This is considerably significant that the mode of teaching does not matter in the Communication and Interaction domain although the role matters in rest of all domains including Planning and Design, Instructor and Learning, Management and Administration, and Technology utilization.

Table 8. Differences in the mean score of teachers' roles in PLEs with regard to their gender

\begin{tabular}{|c|c|c|c|c|c|c|c|c|c|c|c|c|c|c|c|c|}
\hline \multirow{2}{*}{$\begin{array}{c}\text { Socio-De- } \\
\text { mographic } \\
\text { Variables }\end{array}$} & \multirow[b]{2}{*}{ n } & \multicolumn{3}{|c|}{$\begin{array}{l}\text { Planning and } \\
\text { Design }\end{array}$} & \multicolumn{3}{|c|}{$\begin{array}{c}\text { Instructor and } \\
\text { Learning }\end{array}$} & \multicolumn{3}{|c|}{$\begin{array}{l}\text { Communication } \\
\text { and Interaction }\end{array}$} & \multicolumn{3}{|c|}{$\begin{array}{l}\text { Management and } \\
\text { Administration }\end{array}$} & \multicolumn{3}{|c|}{$\begin{array}{c}\text { Use of Tech- } \\
\text { nology }\end{array}$} \\
\hline & & $\sum^{E}$ & 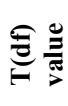 & 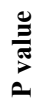 & $\sum_{\Sigma}^{\Xi}$ & 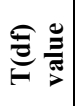 & 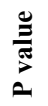 & 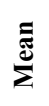 & 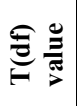 & 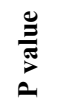 & $\stackrel{E}{E}$ & $\underset{\underbrace{}}{\stackrel{0}{ٍ}}$ & 莺 & $\sum_{\Sigma}^{\Xi}$ & 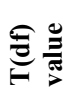 & $\begin{array}{l}\stackrel{0}{E} \\
\stackrel{\pi}{\pi} \\
\text { L }\end{array}$ \\
\hline \multicolumn{17}{|l|}{ Gender } \\
\hline Male & 230 & 4.3 & \multirow{2}{*}{1.10} & \multirow{2}{*}{.26} & 4.2 & \multirow{2}{*}{.907} & \multirow{2}{*}{.32} & 4.2 & \multirow{2}{*}{.218} & \multirow{2}{*}{.827} & 4.2 & \multirow{2}{*}{.180} & \multirow{2}{*}{.858} & 4.2 & \multirow{2}{*}{.652} & .5 \\
\hline Female & 345 & 4.2 & & & 4.2 & & & 4.2 & & & 4.2 & & & 4.3 & & 14 \\
\hline
\end{tabular}

Independent Sample t Test, MD = Mean Difference 
Paper-Teachers' Perspective on Personal Learning Environments via Learning Management Systems...

Table 9. Differences in the mean score of teachers' roles in PLEs with regard to their age groups

\begin{tabular}{|c|c|c|c|c|c|c|c|c|c|c|c|c|c|c|c|c|}
\hline \multirow{2}{*}{$\begin{array}{l}\text { Socio-Demo- } \\
\text { graphic } \\
\text { Variables }\end{array}$} & \multirow[b]{2}{*}{$\mathrm{n}$} & \multicolumn{3}{|c|}{$\begin{array}{c}\text { Planning and } \\
\text { Design }\end{array}$} & \multicolumn{3}{|c|}{$\begin{array}{c}\text { Instructor } \\
\text { and Learning }\end{array}$} & \multicolumn{3}{|c|}{$\begin{array}{l}\text { Communication } \\
\text { and Interaction }\end{array}$} & \multicolumn{3}{|c|}{$\begin{array}{c}\text { Management } \\
\text { and Administra- } \\
\text { tion }\end{array}$} & \multicolumn{3}{|c|}{$\begin{array}{l}\text { Use of Tech- } \\
\text { nology }\end{array}$} \\
\hline & & $\stackrel{\Xi}{\bar{E}}$ & 茛軎 & $\stackrel{\mathscr{E}}{\frac{\mathscr{E}}{2}}$ & 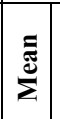 & 造带 & $\frac{\mathscr{O}}{\frac{\mathscr{E}}{\pi}}$ & $\sum_{\Sigma}^{\bar{\varpi}}$ & 永量 & $\underset{\mathscr{E}}{\frac{\mathscr{E}}{\pi}}$ & 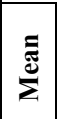 & 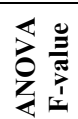 & $\stackrel{\varrho}{\frac{\varrho}{\pi}}$ & $\sum_{\Sigma}^{\Xi}$ & 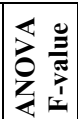 & $\frac{\mathscr{E}}{\tilde{E}}$ \\
\hline \multicolumn{17}{|l|}{ Age } \\
\hline $23-32$ & 188 & 4.3 & \multirow{4}{*}{4.23} & \multirow{4}{*}{.006} & 4.2 & \multirow{4}{*}{1.68} & \multirow{4}{*}{.170} & 4.2 & \multirow{4}{*}{2.48} & \multirow{4}{*}{0.006} & 4.3 & \multirow{4}{*}{1.506} & \multirow{4}{*}{.212} & 4.3 & \multirow{4}{*}{1.395} & \multirow{4}{*}{.243} \\
\hline $33-42$ & 238 & 4.2 & & & 4.2 & & & 4.2 & & & 4.2 & & & 4.3 & & \\
\hline $43-52$ & 127 & 4.2 & & & \begin{tabular}{|l|}
4.2 \\
\end{tabular} & & & 4.2 & & & 4.3 & & & & & \\
\hline $53-62$ & 22 & 3.9 & & & 4.0 & & & 3.9 & & & \begin{tabular}{|l|l|}
4.0 \\
\end{tabular} & & & 4.0 & & \\
\hline
\end{tabular}

One - Way Repeated Measures ANOVA within group analysis was applied followed by Pairwise Comparison with confidence interval adjustment. $\mathrm{MD}=$ Mean Difference.

Table 10. Differences in the mean score of teachers' roles in PLEs with regard to their profession

\begin{tabular}{|c|c|c|c|c|c|c|c|c|c|c|c|c|c|c|c|c|}
\hline \multirow[b]{2}{*}{$\begin{array}{l}\text { Professional re- } \\
\text { lated Variables }\end{array}$} & \multirow[b]{2}{*}{$\mathbf{n}$} & \multicolumn{3}{|c|}{$\begin{array}{c}\text { Planning and De- } \\
\text { sign }\end{array}$} & \multicolumn{3}{|c|}{$\begin{array}{l}\text { Instructor and } \\
\text { Learning }\end{array}$} & \multicolumn{3}{|c|}{$\begin{array}{l}\text { Communication } \\
\text { and Interaction }\end{array}$} & \multicolumn{3}{|c|}{$\begin{array}{c}\text { Management } \\
\text { and Administra- } \\
\text { tion }\end{array}$} & \multicolumn{3}{|c|}{$\begin{array}{c}\text { Use of Technol- } \\
\text { ogy }\end{array}$} \\
\hline & & $\sum_{\bar{\Sigma}}^{\bar{\Xi}}$ & 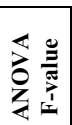 & $\frac{\mathscr{g}}{\bar{E}}$ & $\sum_{\bar{\Sigma}}^{\bar{E}}$ & 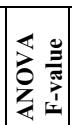 & $\frac{\mathscr{g}}{\bar{E}}$ & $\stackrel{\bar{\varpi}}{\stackrel{\Sigma}{\Sigma}}$ & 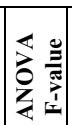 & हू & $\sum_{\bar{\Sigma}}^{\bar{\Xi}}$ & 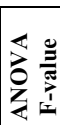 & $\frac{\mathscr{E}}{\sqrt{\pi}}$ & $\sum_{\bar{\delta}}^{\bar{E}}$ & 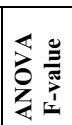 & $\frac{\mathscr{E}}{\overparen{E}}$ \\
\hline \multicolumn{17}{|l|}{ Majors } \\
\hline Social Sciences & 96 & 4.32 & \multirow{6}{*}{4.233} & \multirow{6}{*}{.000} & 4.27 & \multirow{6}{*}{3.22} & \multirow{6}{*}{.004} & 4.24 & \multirow{6}{*}{1.65} & \multirow{6}{*}{.129} & 4.27 & \multirow{6}{*}{2.35} & \multirow{6}{*}{.030} & 4.25 & \multirow{6}{*}{2.903} & \multirow{6}{*}{.009} \\
\hline Sciences & 108 & 4.20 & & & 4.09 & & & 4.16 & & & 4.14 & & & 4.19 & & \\
\hline Mathematics & 100 & 4.30 & & & 4.30 & & & 4.30 & & & 4.34 & & & 4.35 & & \\
\hline English Language & 70 & 4.13 & & & 4.21 & & & 4.21 & & & 4.25 & & & 4.23 & & \\
\hline Computer Sciences & 97 & 4.47 & & & 4.39 & & & 4.40 & & & 4.45 & & & 4.46 & & \\
\hline Other & 104 & 4.18 & & & 4.16 & & & 4.22 & & & 4.22 & & & 4.25 & & \\
\hline \multicolumn{17}{|l|}{ Computer Skills } \\
\hline Beginner & 42 & 3.97 & \multirow{3}{*}{14.04} & \multirow{3}{*}{.000} & 4.05 & \multirow{3}{*}{8.06} & \multirow{3}{*}{.000} & 4.15 & \multirow{3}{*}{5.34} & \multirow{3}{*}{.001} & 4.18 & \multirow{3}{*}{5.35} & \multirow{3}{*}{.001} & 4.11 & \multirow{3}{*}{5.30} & \multirow{3}{*}{.001} \\
\hline Intermediate & 287 & 4.20 & & & 4.16 & & & 4.18 & & & 4.19 & & & 4.23 & & \\
\hline Advance & 247 & 4.41 & & & 4.36 & & & 4.36 & & & 4.39 & & & 4.39 & & \\
\hline \multicolumn{17}{|l|}{ Experience } \\
\hline Less than one year & 67 & 4.10 & \multirow{5}{*}{3.78} & & 4.09 & & & 4.10 & & & 4.18 & & & 4.20 & & \\
\hline One year & 59 & 4.09 & & & 4.03 & & & 4.07 & & & 4.07 & & & 4.15 & & \\
\hline Two years & 84 & 4.26 & & 001 & 4.17 & 383 & 001 & 4.17 & 343 & 000 & 4.13 & 349 & 002 & 4.21 & 240 & 027 \\
\hline Three Years & 103 & 4.37 & & & 4.31 & & & 4.33 & & & 4.42 & & & 4.41 & & \\
\hline $\begin{array}{l}\text { More than three } \\
\text { years }\end{array}$ & 260 & 4.33 & & & 4.31 & & & 4.34 & & & 4.34 & & & 4.32 & & \\
\hline
\end{tabular}

One - Way Repeated Measures ANOVA within group analysis was applied followed by Pairwise Comparison with confidence interval adjustment. MD = Mean Difference. 


\section{Discussion}

\subsection{Teacher's role in planning and design in the PLEs}

These results are in line with Cejudo [9] who claimed that there is a very positive findings from the perspective of teachers about the viability of technical process, instruments as well as performing PLE. In the same vein, Castañeda et al. [14] considered that the PLE is more than ever the pattern for supporting new learning approaches and techniques; particularly for the online contents. The findings of internal and external factors of a learning environment analysis showed teachers were agreed to adjust support accordingly to fit the demands of internal and external factors. These findings are in line with Shaikh and Khoja (2014) who claimed that educators must be the most knowledgeable party that is crucial for the learners to develop connotation among themselves and the PLEs. Consequently, emerging the teachers' perspective in supporting a valuable personalized learning experience is essential [7].

Hence, the statistical information shows near about $86 \%$ of the participants considered teachers' role as learning designer in PLEs including teachers proposed students the constancy of design and functionality across innumerable tools with the purpose of supporting their learning procedures; hence they utilized learning designs which lead to create automatically personalized learning activities. As the findings of Soumplis et al. [15] study claimed that the usage of PLEs in education on the serviceability experience compared to the applied technology behind it attracts more users to develop their experiences.

\subsection{Instructor and learning domain}

The participants declared teachers not only understand behavioural, cognitive, constructive, and social phases of instruction, but also assess the excellence and quantity of students' learning, treated connections between them, as well as utilized collaborative, philosophical, active, and reliable learning approaches once desired. These results agree with several researchers that have suggested that teachers must be provided with adequate professional development, training and staff support for teachers in order to increase their awareness of the complex interplay between technology, pedagogy, and the cognitive content in their disciplines [16-19]. However, research has shown that providing effective training and practice opportunities with technology for teachers is not straightforward [16-18, 20,21]. On the other hand, $52.4 \%$ of teachers fortified students to advance their personal opinions about the world. Students to catch the fundamental source of an effect or an event and the concealed connotation of things. Furthermore, students agreed that teachers' extremely creative role as a learner in PLEs. These results illustrate the importance of role of teachers in PLE [16, 18-20].

Moreover, the findings revealed that teachers developed empathy for students' responses throughout the class and thus, imitated critically on teaching and learning components which reinforced personalized learning. The findings revealed that only $81 \%$ of respondents agreed with the idea of teachers' role as enquirers in PLEs. On the other 
hand, mentoring was approvingly obliged as the subsidiary percentage for this task elevated to 85.6\%. In line with Bagozzi [22] (2007) and Giesbers et al. [23], an important difference is that this study took the actual usage behaviour of the teachers in an experimental setting into account and not just the intention to use it . The respondents $(86.4 \%)$ venerated teachers' role as an innovator in PLEs, as the teachers employed innovative, enhanced, and pioneering teaching and learning methods, learning apparatus, models, simulations, and movies to classify the learning partialities of students, and efficient herself through better learning plans, methods, and possessions when accessible.

\subsection{Communication and interaction}

The majority of respondents agreed with the statement teachers put an extraordinary value on collegiality between students. Ultimately, ease of communication online measure is contained as the latest dimension. Despite The Fact That current study typically just concentrates on few of these dimensions e.g., Ledbetter and Amber [24] claim that, Various justifications for favoring online communication might generate various results. They fortified cooperative learning accomplishments between students and checked students' behaviour to recognize if they work collaboratively. In addition, teachers established an appropriate learning outline through what learners can effortlessly collaborate, connect, and assimilate. Accordingly, participants were agreed that teachers work as an organizer, and claim that teachers managed learning content before it gets complex. According to $84.2 \%$ of responses, teachers put their efforts as good Communicator. In accordance with Bulotsky-Shearer[25] interaction must be constructive in that it is based on the concepts and work from others, such as assisting others in teaching and learning.

Moore [26] declared that students also need to understand the significance of learning communication as an essential part of teaching and learning. Moore [27] examines autonomous students looking for factors which do not affect dialogue and structure to improve their learning experience. Several studies revealed that learner's cooperation with their classmates have an impact on their reaction in relation to their collaboration with their classmates [28, 29]. Furthermore, studies stated that teacher is playing an important role as communication and interaction supporters, since they are responsible for assisting, reassuring, and encouraging interaction and communication between learners [30-33].

Besides, $85 \%$ of participants believed that they showed themselves as good Advertiser. Therefore, teachers' scores to classify components of consensus between students endured high with the support of $85 \%$ of respondents. Hence, participants venerated teachers for their role as advertisers such as adapting the motivating language to endorse a set of standards by students to classify occasions and strategies for cultivating students' recital, and to inspire students to have self-belief. Moreover, $86.4 \%$ of respondents stated teachers work in PLEs as a participant; considered teachers guaranteed the participation of all stakeholders of students' learning procedure and they implied, fortified, recognized, and reinforced students' aids. The findings showed that a teacher is recognized as a motivator among $86 \%$ of study respondents. Thus, mean values in 
this study support the arguments about teachers' role in PLEs within the domain of communication and interactions. Nevertheless, Stroet, et al. [34] effectively studied 71 experimental research about the effects of autonomy-supportive education on learner's motivation and found a clear positive association. Students will not reach the same autonomy level without studying student's autonomy insights, reflecting on their educational experiences, sharing these experiences and reflections with their classmates, and understanding the factors that influence all these procedures [35].

\subsection{Management and administration}

Respondents believed that teachers are decent change mediators, who become effective leaders to motivate students through their personalities which indicates that learners who can evaluate their own learning independently of teacher-centered summative assessments are more likely to become self-regulated students [36]. According to Zimmerman[37], teachers may empower students to assess themselves in the classroom by aiding them in monitoring their learning objectives and strategies, and then making improvements to certain priorities and strategies based on learning performance. It is followed by $86.4 \%$ of responses that presented teachers as Guide to the existing and upcoming learning context of students, expressing approaches that reply to that context, and enhancing the knowledge volume of students by a belief that someday this knowledge will exceed their own. In addition, $85.2 \%$ of participants agreed with the perspective as an administrative manager, a teacher definite what pattern of instructional approaches, presentation genres, and dispersal methods would be best carrying the last program to the learners. Hence, around $85.8 \%$ of participants considered that teachers are Change agents that establish and modify deliberate tasks like how to answer to students' expectations, learning desires, etc. The responses revealed that teachers managed the classroom based on the seats and channels of communication. Thus, the findings portrayed teachers' role as a guide was supposed certainly according to most respondents $(85.8 \%)$. Hence, around $84.8 \%$ of respondents supported that they worked as Evaluator through offering students filtered information about pertinent learning resources according to their preceding experience and through presenting front-end analysis in order to compare definite and perfect performance levels of students.

\subsection{Use of technology}

The results showed that teachers' role in technology use in PLEs has recorded the least results above all domains in teachers' role in PLEs. It is considered that participants claimed that teachers determined when, how, and where suitable learning instruments or skills could be utilized. Moreover, technology use precisely influences electronic learning system deployment then indirectly influences electronic learning systems [38]. Consumer mobility demands to be considered in applying technology to mobile information systems [39]. For a certain technology to be employed, the technology needs a decent correspondence with the task at hand; in a wireless atmosphere, this 
involves location information use [40]. Thus, the geo-location capabilities of smart mobile tools let mobile consumers explore offers in their current zones, saving both effort and time, therefore reaching the technology with the task at hand [41]. Teachers acknowledged approbation as sharer and collector from $83.6 \%$ of participants. However, respondents considered teachers shared e-portfolios, online identities, and learning environments with students. The findings revealed that most respondents were agreed with the statement that teachers support students to master skills required to raise a network of information that works within a flexible structure. Hence, in the perspective of $85.2 \%$ of participants, teachers improved this network of information by illustrating students' consideration of probable content.

Apparently, 85.2\% of participants believed that teachers assessed students' efficiency in consuming the network of information and checked students' development to assure they are working professionally these results are in line with prior research results [41]. Furthermore, teachers supported submissions of learning, learning communities, and groups of learners. In the perspective of $86.4 \%$ of participants, teachers are digital technology experts; because they accomplished students on how to tackle common technological subjects and lead students to familiarize themselves with the changes brought on through new learning technologies these results are agreed by previous research [38]. Then, most participants (87.6\%) considered teachers' tasks as digital literacy experts in PLEs. In this sense, the mean values correspondingly supported the influences underlying the domain of technology employment in PLEs.

\section{Conclusion and future work}

This study considered teachers must occupy specific competencies conducive to a detailed analysis of the E-learning approach. The findings showed that teachers must know how best to integrate the Internet and the content materials. Likewise, teachers must have a solid foundation for the information being delivered to students. In this sense, the findings showed that teachers must recognize the accuracy of the story to deliver students with ethical knowledge. Consequently, according to the finding's students prove a vaster extent of participation. In addition, the findings of this study showed teachers must apply a positive teaching approach, holding that knowledge is composed upon student-to-student interaction as well as student-to-teacher interaction. Furthermore, this study revealed that teachers must enterprise, deliver, and support K12 online learning. Hence, it desires mentioning here that there is little guidance both on the part of reliable research and menu Models to create courses, programs, and experiences to make for the training of novice teachers and preparation of experienced teachers. Moreover, this study considered that teachers must be acquainted with consuming social networking to share information, recognize resources, and obtain new knowledge. Considering evaluation, this study showed that teachers observed that participants presented a preference for difference of delivery process, and their development areas were considered. Finally, the findings of this study deal with the assessment of learning results. In this sense, teachers who expended the students' attainment scores after the involvement found a difference in their performance. Hence, teachers used 
surveys to comprehend better the students' discernments before and after the involvement. Personalize learning platform can also be applied to any other research in Educational Technology area in Augmented Reality [42] [44]. Another future study that can be explored in future is about teacher digital readiness [43].

\section{$7 \quad$ References}

[1] Tuah, N.M., D.S. Ajor, and N. Jamil, Assistive Tools towards Personal Learning Environment in Higher Education. International Journal of Computer Theory and Engineering, 2015. 7(5). https://doi.org/10.7763/IJCTE.2015.V7.993

[2] Conde, M.Á., et al., An evolving Learning Management System for new educational environments using 2.0 tools. Interactive learning environments, 2014. 22(2): p. 188-204. https://doi.org/10.1080/10494820.2012.745433

[3] Gaytan, J., Factors affecting student retention in online courses: Overcoming this critical problem. Career and Technical Education Research, 2013. 38(2): p. 145-155. https://doi.org/10.5328/cter38.2.147

[4] Ellili-Cherif, M. and H.M. Hadba, Fidelity to and satisfaction with prescribed curriculum in an Arab educational context: ESL teachers' perspective. The Curriculum Journal, 2017. 28(3): p. 367-388. https://doi.org/10.1080/09585176.2016.1240885

[5] Mundkur, A. and C. Ellickson, Bringing the real world in: Reflection on building a virtual learning environment. Journal of Geography in Higher Education, 2012. 36(3): p. 369-384. https://doi.org/10.1080/03098265.2012.692073

[6] Aresta, M., et al. Building Identity in an Institutionally Supported Personal Learning Environment-the case of SAPO Campus. in The PLE Conference Proceedings. 2012. Citeseer.

[7] Shaikh, Z.A. and S.A. Khoja, Personal learning environments and university teacher roles explored using Delphi. Australasian Journal of Educational Technology, 2014. 30(2). https://doi.org/10.14742/ajet.324

[8] Martínez Cartas, M.L., Using an improved virtual learning environment for engineering students. European Journal of Engineering Education, 2012. 37(3): p. 229-241. https://doi.org/10.1080/03043797.2012.678985

[9] Cejudo, M.L., Assessing personal learning environments (PLES). An expert evaluation. Journal of New Approaches in Educational Research (NAER Journal), 2013. 2(1). https://doi.org/10.7821/naer.2.1.39-44

[10] Moreillon, J., Building your personal learning network (PLN): 21st-century school librarians seek self-regulated professional development online. Knowledge Quest, 2016. 44(3): p. 64-69.

[11] Schaffert, S. and W. Hilzensauer, On the way towards Personal Learning Environments: Seven crucial aspects. Elearning papers, 2008. 9(2): p. 1-11.

[12] Bolarinwa, O.A., Principles and methods of validity and reliability testing of questionnaires used in social and health science researches. Nigerian Postgraduate Medical Journal, 2015. 22(4): p. 195. https://doi.org/10.4103/1117-1936.173959

[13] Funke, F. and U.-D. Reips, Why semantic differentials in web-based research should be made from visual analogue scales and not from 5-point scales. Field methods, 2012. 24(3): p. 310-327. https://doi.org/10.1177/1525822X12444061

[14] Castañeda, L., N. Dabbagh, and R. Torres-Kompen, Personal learning environments: Research-based practices, frameworks and challenges. 2017. https://doi.org/10.7821/ $\underline{\text { naer.2017.1.229 }}$ 
Paper-Teachers' Perspective on Personal Learning Environments via Learning Management Systems...

[15] Soumplis, A., et al. Implementing an open personal learning environment. in 2011 15th Panhellenic Conference on Informatics. 2011. IEEE. https://doi.org/10.1109/PCI.2011.2

[16] Lawless, K.A. and J.W. Pellegrino, Professional development in integrating technology into teaching and learning: Knowns, unknowns, and ways to pursue better questions and answers. Review of educational research, 2007. 77(4): p. 575-614. https://doi.org/10.3102/ $\underline{0034654307309921}$

[17] Rienties, B., et al., Why some teachers easily learn to use a new virtual learning environment: A technology acceptance perspective. Interactive Learning Environments, 2016. 24(3): p. 539-552. https://doi.org/10.1080/10494820.2014.881394

[18] Rienties, B., N. Brouwer, and S. Lygo-Baker, The effects of online professional development on higher education teachers' beliefs and intentions towards learning facilitation and technology. Teaching and teacher education, 2013. 29: p. 122-131. https://doi.org/ $\underline{10.1016 / j . t a t e .2012 .09 .002}$

[19] Stes, A., et al., Instructional development for teachers in higher education: Effects on students' perceptions of the teaching-learning environment. British Journal of Educational Psychology, 2012. 82(3): p. 398-419. https://doi.org/10.1111/j.2044-8279.2011.02032.x

[20] Ebert-May, D., et al., What we say is not what we do: Effective evaluation of faculty professional development programs. BioScience, 2011. 61(7): p. 550-558. https://doi.org/ $\underline{10.1525 / \text { bio.2011.61.7.9 }}$

[21] Alvarez, I., A. Espasa, and T. Guasch, The value of feedback in improving collaborative writing assignments in an online learning environment. Studies in Higher Education, 2012. 37(4): p. 387-400. https://doi.org/10.1080/03075079.2010.510182

[22] Bagozzi, R.P., U.M. Dholakia, and L.R.K. Pearo, Antecedents and consequences of online social interactions. Media Psychology, 2007. 9(1): p. 77-114. https://doi.org/10.1080/ 15213260709336804

[23] Giesbers, B., et al., Investigating the relations between motivation, tool use, participation, and performance in an e-learning course using web-videoconferencing. Computers in $\mathrm{Hu}-$ man Behavior, 2013. 29(1): p. 285-292. https://doi.org/10.1016/j.chb.2012.09.005

[24] Ledbetter, A.M. and A.N. Finn, Why do students use mobile technology for social purposes during class? Modeling teacher credibility, learner empowerment, and online communication attitude as predictors. Communication Education, 2016. 65(1): p. 1-23. https://doi.org/10.1080/03634523.2015.1064145

[25] Bulotsky-Shearer, R.J., et al., Peer play interactions and learning for low-income preschool children: The moderating role of classroom quality. Early Education and Development, 2014. 25(6): p. 815-840. https://doi.org/10.1080/10409289.2014.864214

[26] Moore, M.G., Learner autonomy: The second dimension of independent learning. Convergence, 1972. 5(2): p. 76 .

[27] Moore, M.G., Th e th eory of transactional distance, in Handbook of distance education. 2013, Routledge. p. 84-103.

[28] Heiser, S., U. Stickler, and C. Furnborough, Student training in the use of an online synchronous conferencing tool. Calico Journal, 2013. 30(2): p. 226-251. https://doi.org/ $10.11139 /$ cj.30.2.226-251

[29] Abuhassna, H., et al., Guidelines for Designing Distance Learning Courses via Moodle to Enhance Students Satisfaction and Achievements.

[30] Fallon Thomas, J., The Use of Students' L1 in the ESL/EFL Classroom and the Role of the Native Speaking Teacher of English. 2015.

[31] Kassandrinou, A., C. Angelaki, and I. Mavroidis, Transactional Distance among Open University Students: How Does it Affect the Learning Process? European Journal of Open, Distance and E-learning, 2014. 17(1): p. 26-42. https://doi.org/10.2478/eurodl-2014-0002 
[32] Mathieson, K., Exploring student perceptions of audiovisual feedback via screencasting in online courses. American Journal of Distance Education, 2012. 26(3): p. 143-156. https://doi.org/10.1080/08923647.2012.689166

[33] Vasala, P. and D. Andreadou, Student's support from tutors and peer students in distance learning. Perceptions of Hellenic Open University "Studies in Education" postgraduate program graduates. Open Education-The Journal for Open and Distance Education and Educational Technology, 2010. 6(1-2): p. 123-137.

[34] Stroet, K., M.-C. Opdenakker, and A. Minnaert, Effects of need supportive teaching on early adolescents' motivation and engagement: A review of the literature. Educational research review, 2013. 9: p. 65-87. https://doi.org/10.1016/j.edurev.2012.11.003

[35] Jacobs, C.T., et al., Experiences with efficient methodologies for teaching computer programming to geoscientists. Journal of Geoscience Education, 2016. 64(3): p. 183-198. https://doi.org/10.5408/15-101.1

[36] Kim, H.J., A.J. Hong, and H.-D. Song, The roles of academic engagement and digital readiness in students' achievements in university e-learning environments. International Journal of Educational Technology in Higher Education, 2019. 16(1): p. 1-18. https://doi. org/10.1186/s41239-019-0152-3

[37] Zimmerman, B.J., Attaining self-regulation: A social cognitive perspective, in Handbook of self-regulation. 2000, Elsevier. p. 13-39. https://doi.org/10.1016/B978-012109890$\underline{2 / 50031-7}$

[38] Al-Samarraie, H., A scoping review of videoconferencing systems in higher education: Learning paradigms, opportunities, and challenges. International Review of Research in Open and Distributed Learning, 2019. 20(3). https://doi.org/10.19173/irrodl.v20i4.4037

[39] Diamond, P.A. and J.A. Hausman, Contingent valuation: is some number better than no number? Journal of economic perspectives, 1994. 8(4): p. 45-64. https://doi.org/10.1257/ jep.8.4.45

[40] Junglas, I., C. Abraham, and R.T. Watson, Task-technology fit for mobile locatable information systems. Decision support systems, 2008. 45(4): p. 1046-1057. https://doi. org/10.1016/j.dss.2008.02.007

[41] Kim, E.Y. and S.H. Yang, Effects of clinical learning environment on clinical practice stress and anxiety in nursing students. Journal of Korean Academy of Nursing Administration, 2015. 21(4): p. 417-425. https://doi.org/10.11111/jkana.2015.21.4.417

[42] Saidin N.F.,Halim N.D.A. \& Yahaya N. (2019), Framework for developing a Mobile Augmented Reality for learning chemical bonds, International Journal of Interactive Mobile Technologies, Vol 13 (7), pg 54 - 68. https://doi.org/10.3991/ijim.v13i07.10750

[43] Perifanou M., Economides A.A. \& Tzafilkou K. (2021), Teachers' Digital Skills Readiness During COVID-19 Pandemic, International Journal of Emerging Technologies in Learning, Vol 16 (8), pg 238-251. https://doi.org/10.3991/ijet.v16i08.21011

[44] Omar M., Ali D.F., Mokhtar M., Zaid N.M., Jambari H., Ibrahim, N.H. (2019), Effects of Mobile Augmented Reality (MAR) towards Students' Visualization Skills when Learning Orthographic Projection, International Journal of Emerging Technologies in Learning, Vol 14(20), pg 106-119. https://doi.org/10.3991/ijet.v14i20.11463

\section{Authors}

Sarah Al Serhan is currently pursuing the Ph.D. degree with the College of Education, Universiti Teknologi Malaysia, Johor. She received the master's degree in Educational Technology from King Saud University, Saudi Arabia. Her research interests 
include educational technology, instructional design, personalize learning, virtual environment.

Associate Prof. Dr. Noraffandy Yahaya is an Associate Professor at Faculty of Education, Universiti Teknologi Malaysia since 2013. He obtained his PhD in Computer Based Learning from University of Leeds, United Kingdom. He was Head of Department at Department of Educational Science, Mathematics and Creative Multimedia for 9 years. Noraffandy has research background in Multimedia in Education, Online Learning and ICT in Education. He conducted studies on students' interaction in online learning environment, Learning Analytics and Massive Open Online Courses (MOOCs). He has published more than 85 papers in Web of Science, Scopus indexed journals, conferences proceedings and non-index journal in the research area of Online Learning, ICT in Education and the use of technology in teaching and learning. He has been a supervisor to more than 25 completed master's degree students and 14 completed $\mathrm{PhD}$ students in the area of Educational Technology, Online Learning and ICT in Education. He had also been appointed as external examiner for universities in Malaysia and Australia for doctoral theses and had been an assessor for Master dissertation for university in New Zealand (email: p-afandy@utm.my).

Article submitted 2021-10-02. Resubmitted 2021-10-27. Final acceptance 2021-10-27. Final version published as submitted by the authors. 